\title{
Concluding Remarks by Pavel Šturma
}

\author{
The International Law Commission and Its Impact: Some Comments
}

It is an ambivalent feeling of honour and anxiety for an author to be called to comment on two excellent papers by Laurence Boisson de Chazournes ${ }^{1}$ and Alejandro Rodiles, ${ }^{2}$ both dealing with the Commission and its impact, yet from different perspectives. The task seems to be even more difficult for someone who is, despite his background in the academia and long-dated practice to follow and comment the work of the International Law Commission, an insider of this body. Being a member of the Commission is a great privilege and a source of the invaluable experience and information. However, after almost seven years in the Commission, the author pays a price for his membership: he cannot pretend to be a mirror or to express "le regard des autres". To put it simply, one can see oneself in the mirror but and be the mirror at the same time.

It is still possible to criticize the mirror for giving a false picture of the object, the Commission in this case. However, this option would not work either in the present case. I mostly agree with the papers presented by the cited authors. What remains is to try to take a certain distance from both the defense of the institution and the views of the commentators.

This paper will be divided in two parts that do not follow closely the structure but rather the nature and underlying ideas of the papers. The first focuses on the changing forms and consequently impact and authority of the works of the Commission. In other words, it considers how the methods of work and outcomes of the International Law Commission have evolved over time (70 years is a sufficient time for evaluation) and what this means for its authority. The second one concerns rather the factors external to the Commission; it discusses its role in new global normative trends. In other words, the Commission does not live in clinical isolation from new developments in international law, as driven by States and other actors, in particular international organizations, and reflected in the doctrine(s) of international law.

\footnotetext{
1 See the contribution by Laurence Boisson de Chazournes in this Section.

2 See the contribution by Alejandro Rodiles in this Section.
} 
True, these two aspects are not exclusive but rather complementary, they can be viewed as two sides of the same coins. Nevertheless, it may be useful to analyze them separately before arriving at some general conclusions. To present my views as an insider to the work of the Commission with regard to the third-party perspectives of Laurence Boisson de Chazournes and Alejandro Rodiles, I will borrow the eyes (optique) of two well-known and provocative intellectuals, namely Woody Allen and Martti Koskenniemi. The latter is a former member of the International Law Commission and greatly contributed to one of its best-known outcomes.

Indeed, Woody Allen did not produce any play or movie about the Commission. However, his film "Midnight in Paris" nicely recalls that it is probably part of human nature that we always look back to a "belle époque" or another kind of golden era.

It is generally accepted and probably true that, if we focus on the number of codification conventions resulting from its work, the "golden era" of codification by the International Law Commission lies in the past, approximately between the end of the 1950s and the first half of 1970s. In other words, one can also speak about the miraculous decade of codification, delimited by 1958 and 1969 , i.e. from the adoption of four Geneva Conventions on the Law of Sea, ${ }^{3}$ going through the codification of diplomatic and consular relations, ${ }^{4}$ to the Vienna Convention on the Law of Treaties. ${ }^{5}$ Many of the instruments adopted during this period still belong to the cornerstones of the contemporary international law. Indeed, the Commission can be proud and refer to such highlights of its codification work.

It is also true that the number of binding instruments adopted on the basis of draft articles from the International Law Commission has dropped in

3 Convention on the Territorial Sea and the Contiguous Zone, adopted 29 April 1958, entered into force 10 September 1964, 516 UNTS 205; Convention on the Continental Shelf, adopted 29 April 1958, entered into force 10 June 1964, 499 UNTS 311; Convention on the High Seas, adopted 29 April 1958, entered into force 30 September 1962, 40 UNTS 11; Convention on Fishing and Conservation of Living Resources of the High Seas, adopted 29 April 1958, entered into force 20 March 1966, 559 UNTS 285 .

4 Vienna Convention on Diplomatic Relations, adopted 18 April 1961, entered into force 24 April 1964, 500 UNTS 95; Vienna Convention on Consular Relations, adopted 24 April 1963, entered into force 19 March 1967, 596 UnTS 261.

5 Adopted 23 May 1969, entered into force 27 January 1980, 1155 UNTS 331. 
number since that time. The reasons for this development depend only partly on the work of the Commission itself. On the one hand, it is an undeniable fact that most parts of general international law have been already codified. Therefore, the Commission more and more often selects new, non-traditional topics that bear on progressive development of international law and even produces outcomes that differ from both codification and progressive development (for example, studies, interpretative guides). ${ }^{6}$ No doubt, different topics require different forms, the International Law Commission thus may use more forms other than the traditional draft articles.

On the other hand, States seem to be less interested in binding treaties today, in particular the general codification conventions elaborated by the expert body, such as the International Law Commission, instead of intergovernmental negotiations. This may push the Commission, in turn, to search for and adopt new, non-traditional topics and methods of work. The role of States and other factors external to the Commission will be addressed in the second part of this contribution.

To be fair, one must acknowledge that the Commission has diversified the forms of its final products. Some of the most authoritative and frequently relied upon instruments that resulted from the work of the Commission are in the form of texts that have not, so far, become multilateral treaties or were never intended to be. The guide to practice on reservations to treaties issued in $2011,{ }^{7}$ for instance, is a significant example of such a non-binding document. It seems that it may be followed by another, though much shorter document, the guide to provisional application of treaties, provisionally adopted by the Commission on first reading in $2018 .^{8}$

The variety of forms of codification does not imply that the Commission does not intend to contribute to the adoption of new multilateral treaties. In recent years, it has recommended to the General Assembly the adoption of conventions on the basis of its draft articles. This was the case with the topic "Protection of persons in the event of disasters", 9 for which the Commission adopted draft articles in 2016 that were taken note of by the General

6 See, for instance, reports of study groups such as 'Fragmentation of international law: difficulties arising from the diversification and expansion of international law - Report of the Study Group of the International Law Commission' (2006) UN Doc A/CN.4/L.682 (hereinafter, "Fragmentation report").

7 ILC, [2011] II(2) ILC Ybk 1, 26.

8 ILC, (2018) UN Doc A/CN.4/L.920 and Add.1.

9 ILC, (2016) UN Doc A/71/10, para 48. 
Assembly, ${ }^{10}$ and it may be the case in relation to the topic "Crimes against humanity" that were adopted on second reading in 2019. ${ }^{11}$

It is true that the last example of the International Law Commission's draft articles that was transformed into a multilateral treaty dates back to 2004 when the United Nations Convention on Jurisdictional Immunities of States and their Property was adopted. ${ }^{12}$ It still took no less than 13 years from 1991 when the Commission had adopted the final text of draft articles on the topic, with commentaries, to the adoption of the Convention. ${ }^{13}$ In accordance with article 23 of its statute, ${ }^{14}$ the International Law Commission submitted the draft articles to the General Assembly, together with a recommendation that the General Assembly convene an international conference of plenipotentiaries to examine them and to conclude a convention on the subject. ${ }^{15}$ The years between 1991 and 2004 were devoted to extensive negotiations conducted first in the open-ended working group of the Sixth Committee, then, on the invitation of the General Assembly, ${ }^{16}$ also within the International Law Commission's Working Group on Jurisdictional Immunities of States and their Property (1999), ${ }^{17}$ and finally in the Ad Hoc Committee on Jurisdictional Immunities of States and their Property (2000-2003). ${ }^{18}$ Although the General Assembly adopted the text of the Convention in December 2004, ${ }^{19}$ this Convention has not yet entered into force. ${ }^{20}$

Why to recall this example? First, it seems that it is not only the community of international lawyers of today (inside or outside the Commission) who have looked back at previous codification efforts. Most likely, our predecessors one or two decades ago also dreamed about the "golden era" of codification in the 196os. The era when almost all final products of the International

$10 \quad$ UNGA Res 71/141 (13 December 2016).

11 ILC, 'Report of the International Law Commission on the work of its seventy-first session' (2019) UN doc A/74/10, 10 at paras 39-41.

12 United Nations Convention on Jurisdictional Immunities of States and their Property (adopted on 2 December 2004, not yet in force) UN Doc A/59/508.

13 ILC, [1991] II(2) ILC Ybk, paras 23 and 28.

14 Statute of the ILC, UNGA Res 174 (II) (21 November 1947) as amended by UNGA Res 485 (V) (12 December 1950).

15 ILC, [1991] II(2) ILC Ybk, para 25.

16 UNGA Res 53/98 (8 December 1998).

17 UNGA Res 54/101 (9 December 1999).

18 Unga Res 55/150 (12 December 2000); Unga Res 56/78 (12 December 2001); Unga Res 57/ 16 (19 November 2002); UNGA Res 58/74 (9 December 2003).

19 UNGA Res 59/38 (2 December 2004).

$20 \quad$ It requires 30 ratifications; as of 1 October 2018, just 22 instruments of ratification have been deposited. 
Law Commission became codification conventions within few years from the submission of the adopted draft articles to the General Assembly. On balance, not all conventions have entered into force and, if so, it also took quite some years.

The second and more important reason is that the experience of the negotiation of the Convention on Jurisdictional Immunities of States may repeat itself with respect to the 2001 articles on responsibility of States for internationally wrongful acts. ${ }^{21}$ Recent debates in the Sixth Committee and several side events organized in New York (such as the one that took place in May 2018, at the margin of the first part of the International Law Commission's seventieth session) have shown that some States would like to have a convention while others continue to be rather reluctant. Members of the Commission also seem divided on the question of a convention. ${ }^{22}$ In principle, once the Commission submitted its final product (for example, draft articles) and made a corresponding recommendation to the General Assembly, it is no longer the master of the product that it passed to the hands of States. However, as the example of the Convention on Jurisdictional Immunities shows, the Commission may be asked by the General Assembly to resume its work and to contribute to clarification of certain issues in the final stage of codification process.

Nevertheless, the impact or authority of the International Law Commission's products does not only depend on the binding nature of a document. Even a non-binding document, resolution or anther soft law product, including the final draft articles with commentaries, may serve the needs of the international community.

One of the best examples has been already mentioned. The codification of the law of State responsibility belongs, together with the law of treaties achieved in the 1969 Vienna Convention on the Law of Treaties, to the most important results of the International Law Commission's codification work. ${ }^{23}$ Unlike the 1969 Vienna Convention, however, the articles on responsibility of States for internationally wrongful acts still remain in a non-binding form. Although proposals to convoke a diplomatic conference have been made more often in recent years, there are still some strong arguments in favour of the status quo. On the request of the Secretary-General, some States responded to the

21 UNGA Res 56/83 (12 December 2001), annex.

22 One of such side events took place already in 2014; see Pavel Šturma, 'Responsibility of States: State of play and the way forward' (2014) Anuario Portugués de Direito Internacional 2013, 93 .

23 Pierre-Marie Dupuy, 'Quarante ans de codification du droit de la responsabilité internationale des Etats. Un bilan' (2003) 107 RGDIP 305, 306. 
question of the final form of the articles. Some of them showed reservations towards the idea of a convention. For example, according to the comments of the United Kingdom,

it is difficult to see what would be gained by the adoption of a convention ... The draft articles are already providing their worth and are entering the fabric of international law through State practice, decisions of courts and tribunals and writings. They are referred to consistently in the work of foreign ministries and other Government departments. The impact of the draft articles on international law will only increase with time, as is demonstrated by the growing number of references to the draft articles in recent years. ... Our view remains that any move at this point towards the crystallization of the draft articles in a treaty text would raise a significant risk of undermining the currently broad consensus on the scope and content of the draft articles. ${ }^{24}$

Arguably, the articles on responsibility of States for internationally wrongful acts are one of the outcomes of the Commission's codification work the impact of which does not depend so much on their form, as both practice and writings refer to the content of the draft articles as an expression of customary international law. Clearly, the level of acceptance of the customary nature of the articles is not the same for all rules contained therein. At the same time, the articles as a whole form a balanced document, covering all the consequences of an internationally wrongful act, at least from the point of view of the Commission. ${ }^{25}$

From this perspective, a convention would be advantageous only if certain conditions were present (and certain risks avoided), ${ }^{26}$ and mostly with respect to some rules in the articles for which their customary nature may be questioned.

This brings the debate to the well-known issue of codification and progressive development of international law. The mandate of the United Nations General Assembly under Article 13, paragraph 1 (a), of the Charter of the United Nations clearly includes the "progressive development of international law

\footnotetext{
24 United Kingdom (2006) UN Doc A/62/63, 6.

25 Cf. Alain Pellet, 'The ILC's Articles on State Responsibility for Internationally Wrongful Acts and Related Texts' in James Crawford, Alain Pellet, Simon Olleson (eds), The Law of International Responsibility (OUP 2010) 86. 
and its codification". ${ }^{27}$ This mandate was specified in article 15 of the Statute of the International Law Commission which provides a definition of these terms. It is clear that the qualification of the topic has an effect on the methods of work to be used by the Commission and also on the form in which progressive development or codification will take place. ${ }^{28}$

As an example, contrary to the articles on responsibility of States for internationally wrongful acts, the draft articles on crimes against humanity (adopted on second reading in 2019) were prepared with a view of a future convention. ${ }^{29}$ Otherwise they could hardly have an expected impact. This does not deny the customary nature of the definition of crimes against humanity, taken over from article 7 of the Rome Statute of the International Criminal Court. ${ }^{30}$ The main added value of the topic lies in the provisions on horizontal (inter-state) cooperation in criminal matters, including criminalization of acts under national law, extradition etc., which may become binding on States only by way of a treaty. It seems that the distinction between codification and progressive development, or even treaty law-making is useful in some cases.

However, this distinction in its strict form proved to be unsustainable in the practice of the Commission and was quickly abandoned. ${ }^{31}$ As pointed out by some eminent commentators and former members of the Commission, the distinction "was hardly defensible scientifically". ${ }^{32}$ Although the actual share may differ from topic to topic, the final products of the Commission comprise elements of both the codification of general international law and of its progressive development.

27 Charter of the United Nations, adopted 24 October 1945, 1 UNTS XVI, Article 13 paragraph (1)(a).

28 Boisson de Chazournes (n 1 ).

29 In the original proposal it was noted by Sean D Murphy that "[a]s such, a global convention on crimes against humanity appears to be a key missing piece in the current framework of international humanitarian law, international criminal law, and international human rights law. The objective of the International Law Commission on this topic, therefore, would be to draft articles for what would become a Convention on the Prevention and Punishment of Crimes against Humanity (Crimes against Humanity Convention)." See ILC, 'Report of the International Law Commission on the work of its sixty-eight session' (2016) UN Doc A/68/10, 140 at para 3.

$30 \quad$ Adopted 17 July 1998, entered into force 1 July 2002, 2187 UNTS 38544.

31 Boisson de Chazournes (n 1).

32 See James Crawford, 'The Progressive Development of International Law' in Denis Alland, Unity and Diversity of International Law: Essays in Honour of Professor Pierre-Marie Dupuy (Brill 2014) 19; Alain Pellet, 'Between Codification and Progressive Development of the Law' (2004) 6 International Law FORUM du droit international 15. 
That is why the revival of the debate on this distinction within the Commission during past few years may appear surprising. One may ask whether this is a sign of uncertainty or a lack of confidence of the International Law Commission, or due to the lack of the traditional topics of general international law that still need codification or a crisis of codification.

The argument of transparency in the work of the International Law Commission has certain merits. There are also some situations where a consensus of the members may depend on the "labeling" of a specific provision (draft article, principle or conclusion) in terms of codification or progressive development. ${ }^{33}$ However, such practice should remain rather exceptional. The generalization or over-use of such qualifications also entails a risk which is not negligible.

Apart from the above-mentioned difficulties to draw a scientifically precise dividing line between "codification" and "progressive development", at least two other problems should be noted. First, the distinction bears a risk for the dynamic process of interrelation between codification and development, or custom and treaty (or other forms of the final product). As is well known, a treaty provision may codify (or be declaratory of) a pre-existing rule of customary international law, or lead to the crystallization of a rule of customary international law, or give rise to (or generating) a new rule of customary international law. ${ }^{34}$

Indeed, this is a dynamic process. It happens quite often that a rule which had not yet been established in its customary form before the adoption of a convention has evolved subsequently into a rule of customary international law. However, the strict labeling of each and every provision (either as codification or progressive development of law) may sometimes downgrade the status of "development" rules and freeze them in this quality.

The most famous product of the International Law Commission, the 1969 Vienna Convention on the Law of Treaties, seems to be the best example of how wise it may be not to overburden individual provisions with such a qualification. Not all articles of the 1966 draft articles that became the 1969 Vienna Convention, including the rules on treaty interpretation, were of a customary nature at that time. Nevertheless, today, they are considered part of customary international law and also applied by those States that did not ratify the 1969 Vienna Convention.

33 See in that regard the contribution by Sean Murphy in Section 5 of this volume.

34 Cf. North Sea Continental Shelf(Merits) [1969] ICJ Rep 3, 38-41. See also draft conclusion 11 in the 'Draft conclusions on identification of customary international law' (2018) UN Doc $\mathrm{A} / 73 / 10,122$. 
The second problem relates to the changing character of the work of the Commission and of its products. Some new topics and the forms of their presentation hardly obey the dichotomy between progressive development and codification. In particular, studies and conclusions such as that on "Fragmentation of international law" (as the most typical example), ${ }^{35}$ but also more recently adopted conclusions on "Subsequent agreements and subsequent practice" 36 or the "Identification of customary international law",37 can be qualified neither as codification nor progressive development of international law. Instead, they have mostly explanatory or interpretative character.

The question if and how the new kinds of final products of the Commission correspond to new normative trends in international law and doctrinal streams is to be addressed in the second part.

\section{Responding to New Challenges, Crisis of Codification and Backlash to International Law}

The "golden era" (and Woody Allen) is over, and it is a time to take the perspective of Martti Koskenniemi who, as an academic, greatly contributed to the articulation of critical studies and a "deconstruction" of international law. It is a kind of paradox that he, as a member of the Commission, also elaborated on the fragmentation of international law and ways how to respond to this phenomenon. As the chair of the Study Group on the topic "Fragmentation of international law: difficulties arising from the diversification and expansion of international law", he contributed, by means of the final report of that Study Group, ${ }^{38}$ to the efforts to counter the fragmentation and work towards the integration of general international law.

According to some commentators, the work of the International Law Commission should change in response to the new normative trends in international law. Such trends also include a preference for informal ways of lawmaking, diluting its frontiers to related fields, mostly international politics, and thus compromising "international law's relative autonomy". ${ }^{39}$ For instance,

35 ILC (n 6) 174.

36 ILC, 'Draft conclusions on subsequent agreements and subsequent practice in relation to the interpretation of treaties' (2018) UN Doc A/73/10, 12.

$37 \quad$ ILC (n 35) 118.

$38 \quad$ ILC (n 6) 174.

39 See Jan Klabbers, 'The Relative Autonomy of International Law or The Forgotten Politics of Interdisciplinarity' (2004) 1 JILIR 35. 
Alejandro Rodiles argues that the trends are of a structural nature. ${ }^{40}$ In other words, he pointed out that the Commission moved, in its study on the fragmentation, from "an analysis of major changes in the system" to the question of the nature of "international law as a legal system".41

It seems to me that it is not possible to disconnect the issue of the end of codification in the traditional sense (the above-discussed crisis of codification or the end of its "golden era"), which also concerns the search for suitable topics, from the pure question of methods (how to perform the tasks) of the Commission. After all, the examples of the new and good practice of the Commission, named by Alejandro Rodiles, are two of the recent topics, namely "Subsequent agreements and subsequent practice" and "Identification of customary international law", which cannot be easily labeled as codification or progressive development of international law.

Indeed, the Commission needs both the new topics, such as the studies on "Fragmentation of international law" or "Subsequent agreements and subsequent practice", and more traditional topics, which continue to be present in its programme of work. The two above-mentioned examples can be best described as interpretative restatements of the relevant areas of international law. Of course, such products have a great potential to contribute to the stability and integration of international law. This seems to be compatible with the mandate of the Commission..$^{42}$ It is clear that a greater variety of topics may require and explain the use of different methods to elaborate and forms to adopt the final products of the Commission. However, the International Law Commission should not cease to pursue its original mandate of codifying and progressively developing international law to the extent that suitable topics are available.

As pointed out by Matthias Forteau, who knows the International Law Commission well from the inside and outside, the Commission may be perceived or criticized as being too "old-fashioned", especially "in a time of deformalization in international law".43 Given its nature as a subsidiary body of

\footnotetext{
40 Rodiles (n 2).

41 Ibid.

42 This seems to result already from the Fragmentation report (ILC (n 6)), and Michael Wood and Arnold Pronto, The International law Commission 1999-2009. Volume IV: Treaties, Final Draft Articles and Other Materials (Ou 2010), 814 ("Thus, it is proposed that the Commission should increasingly look for the avenue of 'restatement' of general international law in forms other than codification and progressive development - not as a substitute but as supplement to the latter.")

43 Mathias Forteau, 'Comparative International Law Within, Not Against, International Law' in Anthea Roberts et al (eds), Comparative International Law (OUP 2018) 166-167.
} 
the United Nations General Assembly, "the ILC operates in a specific context, driven mainly by orthodox attitudes toward international law". ${ }^{44}$ Indeed, this is true. One cannot but agree that the Commission's objective is the preservation of the relative autonomy of international law. Both the composition and the institutional link to the General Assembly makes the Commission a unique organ to fulfill this task.

However, what is not possible to take for granted is the belief of some authors that "deformalization" is the only or main trend in contemporary international law. With due respect, this seems to be highly exaggerated. The evolution and/or changing structures of international law are not an entirely new phenomenon but are one of its features. One should always distinguish between new challenges arising from the practice of States (or other actors) and those produced by the doctrine.

First, considering practice, which is not only but still predominantly State practice, one can discern a trend towards a certain appetite of States for informal instruments. Such informal instruments are concluded, somewhere and sometimes, depending on the areas of international law and politics concerned. At the same time, however, many treaties are still negotiated and concluded in full form, subject to ratification or another expression of the will of the parties to be bound. Maybe States prefer both formal and informal instruments that are results of their political negotiations (where they can advance their priorities) rather than general codification conventions drafted by an expert body.

Another challenge which cannot be well explained by new normative trends (such as deformalization) is the fact that some States prefer bilateralism to multilateral negotiations, which does not speak in favour of the codification or development of general international law. Last but not least, international lawyers, including the Commission, also have to face the recent backlash to international law in general or to some treaty regimes, in areas such as human rights, the International Criminal Court, free trade agreements or investment treaty arbitration. How to respond to such challenges? It seems that the Commission is better prepared to do so by reaffirming the traditional (formalist) legal approach than by embracing new normative trends, in particular if they are still unsettled and sometimes even contradictory. ${ }^{45}$

44 Ibid.

45 According to one view, there exists a so-called autoimmunity symptom by which the Commission itself re-prioritises the priviledged over the unprivileged in the name of democracy. See Yota Negishi, 'The International Law Commission Celebrating its $70^{\text {th }}$ Anniversary: Dresser le bilan pour l'avenir 'à venir' (2018) 7(8) ESIL Reflections. 
Second, considering doctrine, an infinite variety of theoretical approaches and concepts exists in international law scholarship today. Unlike in the past, there is no single predominant school of thought, which could claim authority in the interpretation of law and in legal discourse. If a term could describe the situation in scholarly writings, it would be "theoretical pluralism" or "eclecticism". In such a situation, it would be unlikely (and not advisable) if the Commission took the position of one of the many doctrinal streams. Its place is rather in the mainstream, which is traditional formalism.

However, this does not mean in any way that the Commission cannot and should not be aware of the recent doctrinal trends or open to relevant debates. To the contrary, the International Law Commission is an expert organ, consisting of mostly generalists in international law, coming from both academia and practice. Its expertise and authority would increase rather than decrease if it also took into account, critically and where appropriate, the newest doctrinal streams and projects. As a matter of example, the topic "Succession of States in respect of State responsibility", though only recently put on the Commission's programme of work, refers to two traditional areas of general international law, State succession and international responsibility. While the Special Rapporteur considers the topic to belong to the category of those topics that require progressive development and codification (in the traditional sense), he also looks at and would like to explore the new doctrinal project on "Shared responsibility". ${ }^{46}$ The project certainly merits closer examination before deciding whether it may or may not help the Commission in its work. ${ }^{47}$

\section{Conclusions}

In order to evaluate the impact of the Commission and to propose possible changes in its methods of work, it is important to ask ourselves who we, as the International Law Commission, are and to whom we should speak. In the new circumstances and changing structures of international law, the answer to those questions would be very helpful.

On the one hand, the Commission is an independent expert body. It is not a diplomatic organ although its membership also includes some current or former diplomats, legal advisors, and other categories of government officials.

46 See André Nollkaemper and Ilias Plakokefalos (eds), Principles of Shared Responsibility in International Law (CUP 2014).

47 See Pavel Šturma, 'First report on succession of States in respect of State responsibility' (2017) UN Doc A/CN.4/708, para 133. 
Many members are professors or researchers but this does not make the Commission a purely academic institution. Neither is the International Law Commission a kind of bar associated with the International Court of Justice despite the fact that several members have represented governments as advocates before the Court and some eventually became judges of the Court. To best describe the Commission and its outcomes, I would say that it is a part (maybe a more visible part) of the "invisible college of international lawyers". 48 This also means that the products of the International Law Commission can generally be characterized as writings, unless they are transformed into binding instruments.

On the other hand, the International Law Commission is an official organ of the United Nations and has a large audience. Being a subsidiary organ of the General Assembly, the Commission has to speak to States, mainly through the Sixth (Legal) Committee. In other words, it addresses mostly legal advisors of States. But the audience of the Commission is much larger and includes international courts and tribunals, intergovernmental organizations but also nongovernmental organizations and academia. Of course, all of those constituencies do not have the same but quite different perspectives on international law and expectations of the International Law Commission. This brings to mind Koskenniemi's critical analysis of the different forms of commitment and different professions in international law: the judge, the advisor, the activist and the academic. ${ }^{49}$ Indeed, as he put it, "international law is what international lawyers do and how they think".50

The Commission is in fact the place where theory may (and sometimes does) become practice. This brings about a high level of responsibility and expectations. Indeed, the Commission is not able to meet the expectations of all of its constituencies at the same time. What is too much for a legal advisor of a given State would probably not be enough (and too old-fashioned or conservative) for an activist. It is a natural fate of the Commission (and its members) that it cannot make all of them happy. The Commission could and should be aware of different political agendas and different theories, without giving

48 See Oscar Schachter, 'The Invisible College of International Lawyers' (1977) 72 NULR 217. See also Santiago Villalpando, 'The 'Invisible College of International Lawyers' Forty Years Later' (2013) ESIL 5th Research Forum: International Law as a Profession Conference Paper No. $5 / 2013$.

49 See Marti Koskenniemi, 'Between Commitment and Cynicism: Outline for a Theory of International Law as Practice' in United Nations Office of Legal Affairs, Collection of Essays by Legal Advisors of States, Legal Advisors of International Organizations and Practitioners in the Field of International Law (United Nations 1999) 512-523. Ibid 523 . 
preference to one of them. It may also adopt new topics and methods where appropriate. What matters, however, is to make a best effort and to speak in a language that is understood by all professions and actors of international law. After all, this is what the Commission must do if it wishes to keep its relevance and authority. 
The United Nations - 9789004434271

Downloaded from Brill.come4/26/2023 07:37:48AM via free access 